\title{
СЕЗОННА ДИНАМІКА IНВАЗОВАНОСТІ ТРЕМАТОДАМИ СRУРТОКОТУLЕ LÜHE, 1899 (TREMATODA: HETEROPHYIDAE) РИБ РОДИНИ GOBIIDAE В ЛИМАННИХ ВОДАХ ТА АКВАТОРІЇ ЧОРНОГО МОРЯ ПІВДНЯ УКРАЇНИ
}

\author{
С. Л. Гончаров \\ sergeyvet85@ukr.net
}

Національний університет біоресурсів і природокористування України, вул. Полковника Потєхіна, 16, м. Київ, 03041, Україна

У статті подано результати досліджень поширення та сезонної динаміки зараження бичкових риб: Mesogobius batrachocephalus Pallas, 1814, Neogobius melanostomum Pallas, 1814 ma Neogobius fluviatialis Pallas, 1814 паразитичними трематодами родини Неterophyidaе в лиманних водах $і$ акваторіi Чорного моря Миколаївської та Одеської областей. Встановлено, щзо найбільші показники інвазї̈ були y бичка-кругляка (N. melanostomum) - екстенсивність інвазї склала 59,2 \%. Показники екстенсивності інвазї у бичка-мартовика (M. batrachocephalus) та пісочника (N. fluviatialis) становили 17 mа 30,4\% відповідно. Спостерігали два піки підвищення рівня показників інвазї протягом року - влітку і восени. Було зазначено, що максимальних показників екстенсивності та інтенсивності інвазї криптокотильоз досягає восени. Найбільше заражених риб виявляли серед бичка-кругляка, екстенсивність інвазї була 72,7 \%; у бичка-мартовика та пісочника - 28,5 і 48,1\% відповідно. Влітку загальна кількість інвазованих риб була дещуо меншою. Екстенсивність інвазї у бичка-кругляка характеризувалась найвищими показниками - 57,1 \%. У бичка-мартовика та пісочника ЕІ була 11,1 і 20,1% відповідно. Взимку екстенсивність інвазї̈ у бичка-кругляка була 45,4\%, у бичка-мартовика - 16,6\%, у бичка-пісочника - 30,7\%. Найнижчі показники зараження бичкових видів риб спостерігали навесні порівняно з іншими сезонами року. Показники зараження трематодами родини Неtеrophyidaе бичка-кругляка становили 44,4%, бичка-мартовика 7,14\%, бичка-пісочника - 26,7 \%. Почиреність метацеркаріїв трематод родини Неtеrophyidaе серед бичкових риб у зазначених природних водоймах становила 31,4\%. Інтенсивність інвазї відзначалась найвищими показниками у N. melanostoтит - до 211 метацеркаріїв в одному екземплярі. Найнижчі показники інтенсивності інвазії були у M. batrachocephalus - до 89 личнок паразита.

КЛючові слова: ТРЕМАТОДА, МЕТАЦЕРКАРІЇ, КРИПТОКОТИЛЬОЗ, ПОШИРЕННЯ, СЕЗОННА ДИНАМІКА, БИЧКОВІ РИБИ

\section{THE SEASONAL DYNAMICS OF THE CRYPTOCOTYLE INVASION OF GOBIIDAE FISHESBY THE TREMATODA CRYPTOKOTYLE LÜHE, 1899 (TREMATODA: HETEROPHYIDAE) IN THE ESTUARY WATERS AND IN THE BLACK SEA AREA OF SOUTHERN UKRAINE}

\author{
S. L. Honcharov \\ sergeyvet85@ukr.net
}

National University of Life and Environmental Sciences of Ukraine, 16 Polkovnyka Potekhina str. Kyiv, 03041, Ukraine

The following article is devoted to the results of the analysis of distribution and seasonal dynamics of the cryptocotyle invasion of the fishes from Gobiidae bloodline: Mesogobius batrachocephalus Pallas, 1814, Neogobius melanostomum Pallas, 1814 and Neogobius fluviatialis Pallas, 1814, by the parasitic trematodes from the Heterophyidae bloodline in the estuary waters and the Black Sea area near Mykolaiv and Odesa regions. It has been found out that $N$. melanostomum had the highest rates of invasion - the invasion extensiveness counted $59.2 \%$. The invasion extensiveness of M. batrachocephalus and $N$. fluviatialis counted $17 \%$ and $30.4 \%$ respectively. It was observed that the invasion rates reach their highest points twice a year - in summer and in autumn. It was noted that the maximal rates of the cryptocotyle invasion extensiveness and intensiveness are reached in autumn. The highest percentage of the invaded fishes belonged to N. melanostomum - the invasion extensiveness counted $72.7 \%$. The invasion extensiveness of M. batrachocephalus and $N$. fluviatialis counted - 28.5 and $48.1 \%$. The level of invasion among the fishes slightly dropped down in summer. N. melanostomum could be characterized by the highest invasion 
extensiveness level - 57.1\%. The invasion extensiveness of M. batrachocephalus and $N$. fluviatialis counted $11.1 \%$ and $20.1 \%$, respectively. In winter the invasion extensiveness counted $45.4 \%$ for N. melanostomum, $16.6 \%$ for M. batrachocephalus and $30.7 \%$ for N. fluviatialis. The lowest rates on invasion among Gobiidae fishes were shown in spring, in comparison with other seasons - $44.4 \%$ for N. melanostomum, $7.14 \%$ for M. batrachocephalus and $26.7 \%$ for $N$. fluviatialis. The level of distribution of the metacercaria trematodes from the Heterophyidae bloodline among the Gobiidae fishes in the researched natural waters counted $31.4 \%$. The invasion intensiveness was noted to be at the highest point among $N$. melanostomum - up to 211 metacercaria in one sample. M. batrachocephalus had the lowest rates - up to 89 larvae of the parasite.

Keywords: TREMATODES, METACERCARIA, CRYPTOCOTYLES, DISTRIBUTION, SEASONAL DYNAMICS, GOBIIDAE FISHES

\title{
СЕЗОННАЯ ДИНАМИКА ИНВАЗИРОВАННОСТИ ТРЕМАТОДАМИ СRУРТОКОТУLЕ LÜHE, 1899 (TREMATODA: HETEROPHYIDAE) РЫБ СЕМЕЙСТВА GOBIIDAE В ЛИМАННЫХ ВОДАХ И АКВАТОРИИ ЧЁРНОГО МОРЯ ЮГА УКРАИНЫ
}

\author{
С. Л. Гончаров \\ sergeyvet85@ukr.net
}

Национальный университет биоресурсов и природопользования Украины, ул., Полковника Потехина, 16, г. Киев, 03041, Украина

В статье представлены результаты исследования распространения и сезонной динамики заражения бычковых рыб: Mesogobius batrachocephalus Pallas, 1814, Neogobius melanostomum Pallas, 1814 u Neogobius fluviatialis Pallas, 1814 паразитическими трематодами семьи Неtеrophyidaе в лиманньх водах и акватории Черного моря Николаевской и Одесской областей. Установлено, что наибольшие показатели инвазии были y бычка-кругляка (N. melanostomuт) - экстенсивность инвазии составила 59,2 \%. Показатели экстенсивности инвазии у бычка-мартовика (M. batrachocephalus) и песочника (N. fluviatialis) составляли 17 и 30,4\% coответственно. Наблюдали два пика повышения уровня показателей инвазии в течении года - летом и осенью. Было отмечено, что максимальных показателей экстенсивности и интенсивности инвазии криптокотилёз достигает осенью. Больше всего зараженных рыб обнаруживали среди бычка-кругляка, экстенсивность инвазии была 72,7\%; у бычка-мартовика и песочника - 28,5 и 48,1 \% соответственно. Летом общее количество инвазированных рыб было несколько меньше. Так, экстенсивность инвазии у бычка-кругляка характеризовалась высокими показателями - 57,1 \%. В бычка-мартовика и песочника ЭИ была 11, 1 и 20,1\% соответственно. Зимой экстенсивность инвазии у бычка-кругляка была 45,4\%, у бычка-мартовика - 16,6\%, у бычка-песочника 30,7 \%. Самые низкие показатели заражсения бычковых видов рыб отмечали весной по сравнению с другими сезонами года. Показатели заражения трематодами семьи Неtеrорhyidaе бычка-кругляка составляли 44,4\%, бычка-мартовика - 7,14\% и у бычка-песочника - 26,7\%. Распространенность метацеркарии трематод семьи Неtеrорhуідае среди бычковых рыб в указанных природных водоемах составила 31,4\%. Интенсивность инвазии отмечалась высокими показателями у N. melanostoтит - до 211 метацеркарии в одном экземпляре. Самые низкие показатели интенсивности инвазии были у M. batrachocephalus - до 89 личинок паразита.

Ключевые слова: ТРЕМАТОДА, МЕТАЦЕРКАРИИ, КРИПТОКОТИЛЁЗ, РАСПРОСТРАНЁННОСТЬ, СЕЗОННАЯ ДИНАМИКА, БЫЧКОВЫЕ РЫБЫ

Найбільш тісні взаємини паразитів з хазяями виникають тоді, коли ті оселяються безпосередньо у їх тканинах. У таких випадках негативний вплив паразитів на гомеостаз організму хазяїна найбільш гостро відчувається через механічні пошкодження тканин, порушення обмінних процесів та роботи імунної системи, що нерідко супроводжується важкими клінічними проявами та високою летальністю [16]. Саме такими паразитами риб є метацеркарії родини Het- erophyidae. В роді нараховується 8 видів: Cryptocotyle concava Creplin, 1825; Cryptocotyle lingua Creplin, 1825; Cryptocotyle jejuna Nicoll, 1907; Cryptocotyle badamshini Kurochkin, 1959; Cryptocotyle cryptocotyloides Issaitschikow, 1923; Cryptocotyle delamurei Jurachno, 1987; Cryptocotyle quinqueangularis Skrjabin, 1923; Cryptocotyle thapari McIntosh 1953 [2, 5, 6]. Це трематоди, першими проміжними хазяями яких $є$ черевоногі молюски, а остаточними — рибоїдні птахи [17]. 
Досі залишається недостатньо вивченим поширення криптокотильозу риб в Україні. Нез'ясовано багато питань щодо біології збудника. У літературі неоднозначно висвітлено патогенний вплив цього паразита на організм хазяїна. Недосліджено повністю патогенез та невідомо про роль різних рибоїдних птахів у циркуляції паразита. Існує також ймовірність зараження людини як потенційного остаточного хазяїна для цього паразита.

Збудник криптокотильозу паразитує у кишках рибоїдних птахів, морських ссавців, собак, а також людини $[7,12,16]$. Проміжна стадія розвитку, метацеркарій, паразитує в тканинах риб, здебільшого родини Gobiidae [18].

Встановлено поширення цього паразита у морських та лиманних водах низки країн: Росії, Німеччини, Болівії, Великобританії, Болгарії, Франції, Молдови, Польщі тощо [4, $9,14,18]$. На території України зареєстровано паразитування $C$. jejuna у Керченській протоці у чайки Larus cachinnans Pallas, 1811. Представників цього виду на зазначеній території раніше не реєстрували [10].

Проміжними хазяями паразита є молюски Hydrobia ulvae (Peringia ulvae) Pennant, 1777, які заселили води Атлантичного океану. Останні, як відомо, омивають Великобританію, Францію та Ірландію [3, 18]. В Україні зареєстровано паразитування збудника криптокотильозу у молюсків Hydrobia acuta Pennant, 1777 [11].

Наявні літературні джерела обмежено описують біологію збудника, патогенез хвороби в риб, хоча й підтверджують факт його широкого поширення на території багатьох країн. Водночас даних щодо поширення трематоди родини Heterophyidae у риб на території України майже немає.

За повідомленням низки науковців, метацеркарії трематоди родини Heterophyidae становлять небезпеку для здоров'я людини при споживанні риби та рибної продукції, яка пройшла недостатню кулінарну обробку $[7,12,16]$. Також паразитування статевозрілих трематод у шлунково-кишковому каналі спостерігали у котів, собак та морських ссавців $[4,17,18]$.

Метою дослідження було проведення аналізу сезонної динаміки зараження личинками паразитичної трематоди родини Hetero- phyidae бичкових риб, виловлених у районі акваторій Дніпро-Бузького лиману і Чорного моря Миколаївської та Одеської областей.

\section{Матеріали і методи}

Упродовж 2015-2018 pр. було досліджено 572 особини бичків різних видів. Іхтіопатологічне дослідження проходили всі види риб, які належали до родини Gobiidae. Клінічне дослідження проводили, уважно оглядаючи поверхню луски та шкірних покривів. Окремо досліджували ротову та зяброву порожнини. Черевну порожнину розтинали розрізом, який починали від анального отвору та спрямовували до голови. Кожен орган препарували та відокремлювали; окремо відділяли і досліджували кишечник та його вміст. Для дослідження м'язової тканини попередньо знімали шкіру. Поперечні надрізи м'язів проводили під косим кутом до хребта; кожен надріз проглядали на яскравому світлі. Виокремлювали і досліджували головний та спинний мозок, а також кришталик ока [1].

За умов розтину тканини відбирали і досліджували компресорним методом за допомогою компресорію МИС-7. Мікроскопію проводили за допомогою оптичного обладнання: мікроскопа тринокулярного Micromed XS-4130 та мікроскопа бінокулярного стереоскопічного Micromed XS-6320. Метацеркарії виявляли на поверхні тіла, плавцях, а також на зябрах риб родини Gobiidae: M. batrachocephalus, N. elanostomum, $N$. fluviatialis. Після виділення метацеркаріїв з навколишніх тканин проводили ексцистування, тобто виділення личинки трематоди з оболонок цисти. Виділені цисти поміщали в $0,5 \%$ розчин хімотрипсину, нагрітого до температури $38-40{ }^{\circ} \mathrm{C}$, та витримували 7-10 хв. Внаслідок цього навколишні тканини починали лізуватися і циста легко вилучалася з залишків тканин за незначного механічного впливу.

Вилучені цисти переносили на предметне скло та вносили тонкий шар гліцерину. Для фіксації і розривання капсули використовували медичні скарифікатори для взяття капілярної крові, які для зручності фіксували у гемостатичному пінцеті під кутом $45^{\circ}$ щодо уявної осі його закритих браншів. Одним скарифікатором фіксували метацеркарій, а іншим обережно 
розривали стінку цисти, далі метацеркарій протягом 1 хв самостійно покидав цисту без додаткових механічних маніпуляцій [15].

\section{Результати й обговорення}

За мікроскопії гепатопанкреаса, жовчного міхура, кришталика ока, а також тканин серця, нирок, мозку метацеркаріїв не виявляли. Водночас за мікроскопії поверхневих тканин, відібраних з різних ділянок тіла риби, зокрема плавців та зябер, знаходили метацеркарії $C$. jejuna i C. cancavum (рис. 1).

Ексцистовані метацеркарії C. cancavum мали тіло овальної форми завдовжки 0,42 мм і завширшки 0,37 мм. Кутикула - щільна, вкрита дрібними шипиками. Ротова присоска термінальна, округла, 0,055 мм у діаметрі. Пре-

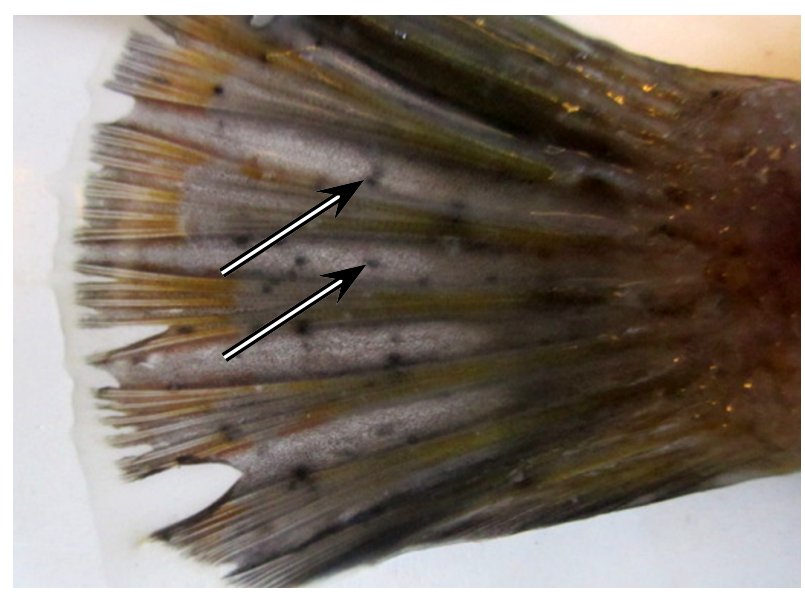

Puc. 1. Метацеркарії трематоди родини Heterophyidae на хвостовому плавці $N$. fluviatialis

Fig. 1. Metacercariae of trematodes of Heterophyidae family on the caudal fins of $N$. fluviatialis

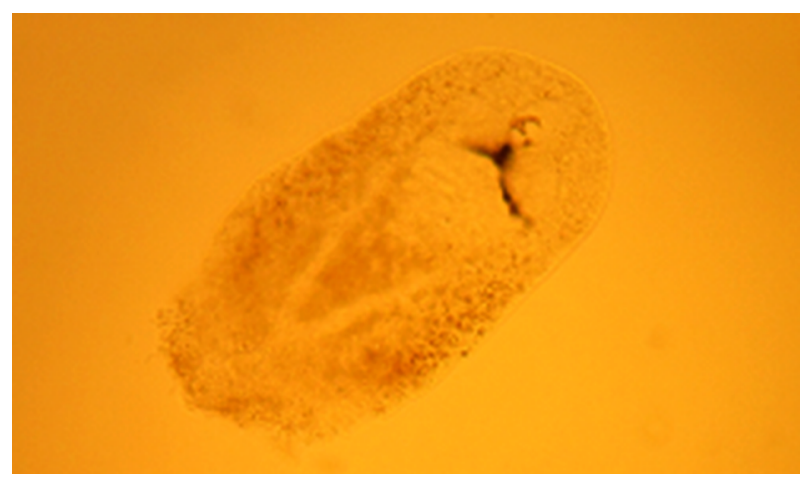

Puc. 2. Ексцистований метацеркарій трематоди Cryptocotyle concava. Нативний препарат. Збільшення $\times 280$

Fig. 2. Encysted metacercaria of Cryptocotyle cancavum trematodes. Native. $\times 280$ фаринкс короткий - 0,011 мм, фаринкс овальний, 0,038 мм; за ним слідує розгалуження кишкової трубки, стовбури якого спрямовані до каудальної частини тіла та сліпо закінчуються позаду сім'яників. Статевий синус з рудиментарною черевною присоскою, округлої форми, розміщений у задній частині тіла. Екскреторний орган відкривається на кінці тіла (рис. 2).

Велику зацікавленість становили метацеркарії $C$. јејипа, оскільки раніше в акваторіях зазначеної ділянки природних водойм півдня України їх не реєстрували. Цисти у них мали овальну форму. Тіло метацеркарій було видовжено-овальної форми, дещо загострене спереду та заокруглене ззаду. Кутикула вкрита дрібними шипиками. Ротова присоска субтермінальна, 0,048 мм. Префаринкс добре виражений, 0,013 мм, фаринкс невеликий, кулеподібний. Стравохід за довжиною дорівнює префаринксу. Кишкові стовбури добре візуалізуються та сліпо закінчуються в задній частині тіла, огинаючи зачатки сім'яників $[2,5,6]$.

Аналіз сезонної динаміки захворюваності бичка-мартовика (Mesogobius batrachocephalus) на криптокотильоз засвідчив, що найбільших показників зараження інвазія набувала восени та взимку. Восени показники екстенсивності інвазії (ЕI) за цього захворювання становили $28,5 \%$, а взимку - 16,6 \%. Інтенсивність інвазії в бичків цього виду була найбільшою влітку та восени і коливалась в діапазоні 18-78 та 21-89 екз. відповідно. Показники ЕІ навесні були найменшими протягом усього періоду спостережень і становили 7,14 \%. II навесні становила 54 метацеркарії. Така ситуація виникла, оскільки у вказаний період року була можливість дослідити лише один екземпляр риби зазначеної видової належності. Влітку показники ЕІ за криптокотильозу становили 11,1 \%, а II була на рівні 89 метацеркаріїв криптокотилюсів, що було виявлено в одній рибі при проведенні іхтіопатологічного дослідження (табл.). Показники інвазування бичка-кругляка (Neogobius melanostomum) відзначалися найбільшими показниками інвазії восени: ЕІ становила 72,7 \%, амплітуда II - 93-211 метацеркаріїв трематод. Навесні показники EI характеризувалися як найменші протягом року і становили 44,4 \%, але показники II, порівняно з іншими сезонами, були високими, 
Сезонна динаміка інвазованості бичкових риб метацеркаріями трематоди родини Heterophyidae в акваторії лиманних вод та Чорного моря півдня України $(\mathbf{n}=572)$

Seasonal dynamics of prevalence and intensity of infection with metacercariae of Heterophyidae in fish of Gobiidae family in estuary waters and the Black Sea in Southern Ukraine $(n=572)$

\begin{tabular}{|l|c|c|c|c|c|c|c|c|c|}
\hline \multirow{3}{*}{ Пора року / Season } & \multicolumn{9}{|c|}{ Вид риб / Species of fish } \\
\cline { 2 - 10 } & \multicolumn{1}{|c|}{ Mesogobius batrachocephalus } & \multicolumn{2}{c|}{ Neogobius melanostomum } & \multicolumn{3}{c|}{ Neogobius fluviatialis } \\
\cline { 2 - 10 } & $\mathrm{n}$ & EI, \% & II, ек3 & $\mathrm{n}$ & EI, \% & II, ек3 & $\mathrm{n}$ & EI, \% & II, ек3 \\
\hline Bесна / Spring & 14 & $7,14(1)$ & 54 & 9 & 44,4 & $56-174$ & 71 & 26,7 & $9-33$ \\
\hline Літо / Summer & 18 & 11,1 & $18-78$ & 7 & 57,1 & $41-115$ & 208 & 20,1 & $21-82$ \\
\hline Осінь / Autumn & 21 & 28,5 & $21-89$ & 22 & 72,7 & $93-211$ & 133 & 48,1 & $23-124$ \\
\hline Зима / Winter & 6 & $16,6(1)$ & 13 & 11 & 45,4 & $67-141$ & 52 & 30,7 & $37-74$ \\
\hline
\end{tabular}

а саме на рівні 56-174 метацеркарія трематоди родини Heterophyidae. Влітку показники інвазії, порівняно з весною, зростали. Так, ЕІ протягом літа була 57,1 \%, а інтенсивність інвазії становила 41-115 личинок трематод. Показники II у бичка-кругляка були найнижчими за криптокотильозу саме влітку. Взимку кількість заражених риб зменшувалась до 45,4 \% порівняно з попереднім сезоном року. Так само знижувалися показники амплітуди II і становили 67-141 паразитів, встановлених на досліджуваних рибах.

Зараження криптокотилюсами бичкапісочника (Neogobius fluviatialis) набувало найбільших показників восени. Так, показники ЕІ становили 48,1 \% за середньої амплітуди II 23-124 личинки досліджуваного паразита.

Найменшими показниками ЕІ за криптокотильозу у бичка-пісочника характеризувалось літо. Влітку показники інвазованості досягали 20,1 \% від загальної кількості досліджуваної риби цього виду. Показники II у літній період були в діапазоні мінімальних та максимальних кількостей виявлених метацеркаріїв паразита - 21-82 личинки. Навесні відзначали ЕI на рівні $26,7 \%$, а показники II були найнижчими з усіх досліджуваних сезонів року - 9-33 паразита. Взимку рівень інвазії спадав порівняно 3 осіннім сезоном. Так, ЕІ протягом зими досягала 30,7 \%, а показники II були на рівні 37-74 метацеркаріїв трематоди родини Heterophyidae.

Цікаво зауважити, що, за нашими спостереженнями, найбільше уражених бичків досліджуваних видів було зареєстровано саме восени. Аналізуючи детально таблицю, можна дійти висновку, що рівні зараженості бичкових риб збудником криптокотильозу протягом року відносно рівномірно розподілені і немає значних коливань показників зараженості. Це означає, що, незалежно від сезону року, повної елімінації збудника з організму проміжного хазяїна - бичкових риб - не відбувається. Необхідно зазначити, що ступінь інвазованості гідробіонтів надзвичайно залежить від біологічних особливостей власне бичків: тип живлення та середовище існування, період нересту, поведінкові особливості під час розмноження, наявності чи відсутності великих скупчень дефінітивних хазяїв - рибоїдних птахів тощо.

$N$. melanostomum та $N$. fluviatialis є типовими молюскофагами, які живляться переважно молюсками - Mytilaster lineatus та Syndesmia ovata, а також молюсками роду Cardiidae. Рідше основою раціону можуть бути і молюски Hydrobia ulvae, які є першими проміжними хазяями для криптокотилюсів. N. fluviatialis також збагачує свій раціон і ракоподібними, що відповідно відображається на різноманітті його паразитофауни. Поїдаючи молюсків, бички паралельно 3 цим інвазуються. Для церкаріїв трематоди родини Heterophyidae характерною $є$ наявність позитивного фото- та геотаксису. Бичкові риби переважно донні чи придонні, що додатково сприяє інвазуванню останніх. Зазначені види бичків надають перевагу прибережній місцевості, піщаним мілинам, іноді з м'яким мулистим або кам'янистим дном [13].

Бичок-кругляк та пісочник $є$ достатньо рухливими видами риб, які в пошуках кормової бази здійснюють незначні кормові та сезонні міграції в межах певних ділянок лиманних та морських акваторій. Їхній стиль існування сприяє зараженню збудниками криптокотильозу, оскільки вони $\epsilon$ переважно донними рибами. Під час пошуку молюсків інтенсивно заражаються церкаріями трематоди роду Heterophyidae, рух яких спрямований до поверхні дна. 
M. batrachocephalus є типовим хижаком, який переважно полює на інші види риби: чорноморську кільку, хамсу, атерину, тюльку тощо. Роль бентосу в раціоні цього виду бичків незначна, а тому й рівень інвазованості є найнижчим з усіх досліджуваних нами риб родини Gobiidae. Бичок-мартовик як хижак, що полює з засідки, $\epsilon$ менш рухливим видом, а тому ймовірність інвазуватися церкаріями трематод $є$ меншою.

Активність поїдання кормів зростає з початком вегетативного періоду гідробіонтів, тобто навесні. Саме у весняно-літній період року настає нерест. Дуже важливо зазначити, що самиці лише відкладають ікру, а будову та охорону гнізда до моменту викльову личинок покладено на самця. За час догляду за гніздом самці дуже мало та погано споживають корм, рухаючись в невеликому периметрі акваторії водойми і надзвичайно виснажуються $[3,13]$. Виснаження та обмежене споживання корму, зниження резистентності і опірності організму є додатковим фактором, що сприяє різноманіттю їх паразитофауни. Саме тому, за результатами наших досліджень, рівень ЕІ у самців бичкових риб є на 25,3 \% більшим, аніж у самиць. Велика кількість ослаблених самців за високих показників інвазованості, незадовільної вгодованості та невідповідностей гідрохімічних режимів гине наприкінці нерестового періоду або незабаром після нього. 3 цісї причини, на нашу думку, відбуваються літні коливання показників інвазованості.

Дифінітивні хазяї цих паразитів також мають велике значення як у розповсюдженні захворювання, так і підтриманні постійних вогнищ інвазії в певних ділянках акваторій Дніпро-Бузького лиману та Чорного моря. Створення сміттєзвалищ поблизу великих міст (Миколаєва, Одеси, Південного та Чорноморська) сприяє появі осілі колонії рибоїдних птахів, переважно чайкових, які цілорічно підтримують на одних і тих же територіях водойм невеликі осередки інвазії. Цьому сприяють обмежені та недовготривалі міграції бичкових риб. Лише бичок-мартовик після нересту переходить до більш глибоководного способу життя, що певною мірою обмежує інтенсивність зараження метацеркаріями криптокотилюсів.

Значний антропогенний вплив, який полягає в органічному забрудненні водойм, в результаті створює комфортніші умови для першого проміжного хазяїна збудника криптокотильозу - молюсків, що в подальшому лише поглиблює проблему поширення небезпечного захворювання. Зміна міграційних шляхів перелітних птахів або й відмова від міграцій, а також їх затримка на місцях відпочинку та масової годівлі через довготривалі відносно теплі погодні умови в осінньо-зимовий період є фактором, який призводить до пікових показників EI у бичків за криптокотильозу саме восени.

Колонії птахів, як правило, мають чіткі локалітети, обумовлені відповідними умовами існування: наявність кормової бази, певна віддаленість від населених пунктів, наявність жорсткої водної рослинності та чагарників, мілинні піщані намиви створюють для рибоїдних птахів комфортні умови для гніздування та виведення потомства. За такого скупчення кінцевих хазяїв разом з фекальними масами у воду потрапляють і яйця криптокотилюсів, які інвазують перших проміжних живителів - молюсків. Так формуються локальні осередки інвазії. Локальності також сприяє той факт, що молюски, зокрема й Hydrobia ulvae, є не надто рухливими організмами і скупчуються в місцях, багатих на органічні рештки, і на мілководді, яке добре прогрівається.

Тому ліквідація та профілактика гельмінтозоонозів, у тому числі криптокотильозу, повинна грунтуватися на періодичному аналізі та вивченні поширеності цієї інвазії на певних локалітетах акваторій, а також визначенні причин, які сприяють цьому процесу. Вивчення біологічних особливостей збудника, зокрема сезонної динаміки інвазування бичків, дозволяє глибше зрозуміти вплив низки факторів на процеси інтенсивності зараження. Отримані наукові дані можуть слугувати фундаментальною та науково-обгрунтованою основою для розробки запобіжних заходів 3 метою профілактики зараження людей криптокотильозом та недопущення подальшого поширення небезпечного паразитозу в басейнах природних водойм півдня України.

\section{Висновки}

1. Середня екстенсивність інвазії серед бичків у досліджуваних водоймах становила $31,4 \%$. 
2. Найбілыші показники інвазії серед риб родини Gobiidae спостерігаються переважно влітку та восени, але пік інвазії припадає на осінь.

3. Встановлена залежність ступеня зараженості від статі бичкових риб: показники ЕI у самців $є$ на 25,3 \% більшими проти самок, що пояснюється їхнім біологічним циклом.

4. Екстенсивність інвазії у M. batrachocephalus була $17 \%$, а у N. melanostomum та $N$. fluviatialis - 59,2 та 30,4 \% відповідно.

5. Показники інтенсивності інвазії серед бичків досягали 211 личинок трематод в одному екземплярі $N$. melanostomum. Меншою кількістю відзначалися $N$. fluviatialis i M. batrachocephalus - 124 і 89 екз. відповідно.

Перспективи подалыших досліджень. Трематоди родини Heterophyidae є досить поширеними в акваторіях Дніпро-Бузького лиману і прибережної зони Чорного моря Миколаївської та Одеської областей. Зазначені паразити становлять небезпеку зараження людини. Детальне вивчення біології збудника, його поширення та спричинені зміни в організмі неспецифічних хазяїв $є$ актуальним питанням моніторингу інвазійних хвороб промислових водойм. Враховуючи можливий патогенний вплив збудника криптокотильозу на організм тварин, необхідно досліджувати вікову динаміку та локалізацію збудника криптокотильозу в тілі проміжного хазяїна - бичкових риб.

1. Bikhovskaya-Pavlovskaya I. E. Parasites of fish.A study guide. Nauka, Leningrad, 1985, pp. 1- 121. (in Russian)

2. Bray R. A. Gibson D. I., Jones A., Keys to the Trematoda. Vol. 3. Wallingford, CABI Publ., 2008, 824 p. DOI: 10.1079/9780851995885.0000.

3. Field L. S., Irwin S. B. W. Digenean larvae in Hidrobia ulvae from Belfast Loungh (Northern Ireland) and the Ythan Estuary (North-East Scotland). Journal of the Marine Biological Association of the United Kingdom, 1999, vol. 79, issue 3, pp. 431-435. DOI: $10.1017 / \mathrm{S} 0025315498000551$.

4. Gardner S. L., Thew P. T. Redescription of Cryptocotyle thapari McIntosh, 1953 (Trematoda: Heterophyidae), in the river Otter Luttra longicaudis from Bolivia. Comparative Parasitology, 2006, vol. 73, issue 1, pp. 20-23. DOI: 10.1654/0001.1.

5. Gibson D. I., Jones A., Bray R. A. Keys to the Trematoda. Vol. 1. Wallingford, CABI Publ., 2002, 521 p. DOI: 10.1079/9780851995472.0000.

6. Jones A., Bray R. A., Gibson D. I. Keys to the Trematoda. Vol. 2. Wallingford, CABI Publ., 2005, 768 p. DOI: $10.1079 / 9780851995878.0000$.
7. Kurochkin Y. V. Biserova L. I. On the etiology and diagnosis of "black-and-spotted diseases" of fish. Parasitologiya, 1996, vol. 30, issue 2, pp. 117-125. (in Russian)

8. Malek M. Parasites as discrimination Keys in two sympatric species of gobies. Bulletin of European Association of Fish Pathologists, 2004, vol. 24, issue 4, pp. 173-179. Available at: https://www.researchgate. net/publication/234033329 Parasites as discrimination_keys_in_two_sympatric_species_of_gobies

9. Martynenko I. M. A About morphological differentiation of species of the genus Cryptocotyle. Modern problems in theory and Marine Parasitology, Sevastopol, 2016, 242 p. (in Russian)

10. Martynenko I. M. On the finding of Cryptocotyle jejuna (Nicoll, 1907) Ransom, 1920 in the Kerch Strait. Reports of the conference of young researchers zoologists. Institute of Zoology NAS of Ukraine, Kyiv, 2012, p. 21. (in Ukrainian)

11. Martynenko I. M., Kornyychuk Y. M. Trematodes Cryptocotyle jejuna in mollusks Hydrobia acuta in the Kerch Strait. XV conference of Ukrainian Scientific Society of Parasitologists, Chernivtsi, 2013, p. 58. (in Russian)

12. Moshu A. Helminthes of fish ponds between the rivers Dnister and Prut, potentially dangerous to human health. Kishineu, Eco-Tiras, 2014, 88 p. (in Russian)

13. Naidenova N. N. Parasites Fauna of fishes of the family Gobiidae of the Black and Azov Seas. Kyiv, Naukova Dumka, 1974, 183 p. (in Russian)

14. Rolbiecki L. Parasites of the round goby Neogobius melanostomus (Pallas, 1811), an invasive species in the Polish fauna of the Vistula Lagoon ecosystem. Oceanologia, 2006, vol. 48, issue 4, pp. 545-561. Available at: http://yadda.icm.edu.pl/yadda/element/ bwmeta1.element.agro-article-d6439c12-eb0242c0-9ce2-b186af8c9311

15. Soroka N., Goncharov S. Method of allocation metacercariae trematodes Paracoenogonimus ovatus. The applicant and patentee National University of Life and Environmental Sciences of Ukraine no. 103347 ; 06.25.2015 claimed; publ. 12.10.2015, bull. no. 23 .

16. Sudarikov V. J., Lomakin V. V., Atajev A. M., Semenova N. N. Metacercaria of trematodaes, parasites of fish in the Caspian Sea and the Volga River Delta. Moscow, Nauka, 2006, pp. 1-183. (in Russian)

17. Thieltges D. W., Ferguson A. D., Jones C. S., Noble L. R., Poulin R. Biogeographical patterns of marine larval trematode parasites in two intermediate snail host in Europe. Journal of Biogeography, 2009, vol. 36, issue 8, pp. 1493-1501. DOI: 10.1111/j.1365-2699.2008.02066.x.

18. Thieltges D. W., Krakau M., Andresen H., Fottner S., Reise K. Macroparasite community in molluscs of a tidal basin in the Wadden Sea. Helgoland Marine Research, 2006, vol. 60, pp. 307-316. DOI: 10.1007/s10152-006-0046-3. 